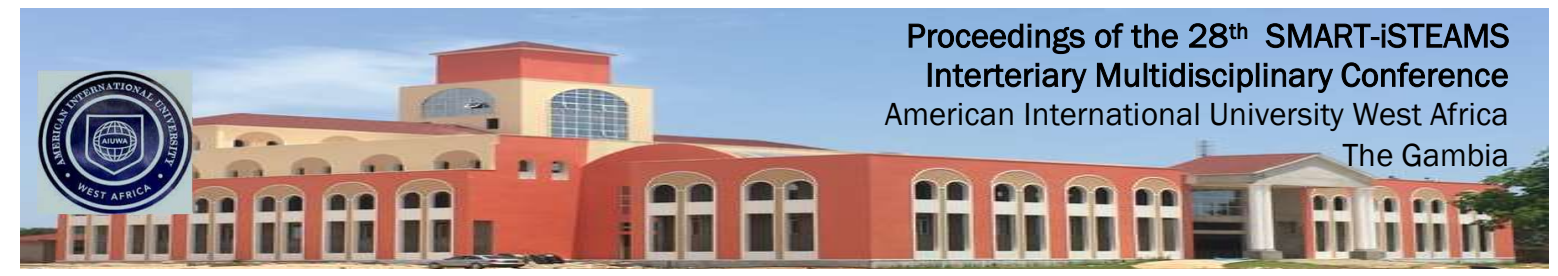

\author{
Full Research Paper
}

\title{
Assessment of Dominative and Integrative Behaviour of Yoruba Language Teachers in Senior Secondary Schools in Oyo State Nigeria
}

\begin{abstract}
Abijo, J.A. (PhD)
Institute of Education University of Ibadan Ibadan, Nigeria

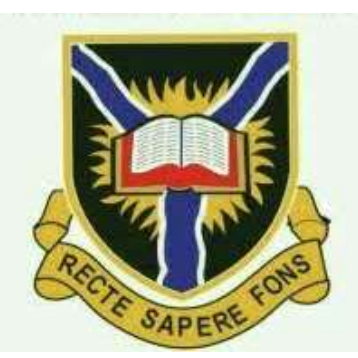

E-mails jaabijo@gmail.com

Phone $+2348033510187$
\end{abstract}

\begin{abstract}
Teacher-student interaction has been a concept that has been researched on for some years now. However, there seem to be paucity of researches that look at the dominative and integrative behaviour of teachers in the classroom. This study therefore was a survey work carried out to assess the integrative and dominative behaviour of Yoruba language teachers in senior Secondary Schools in Oyo State. To attain the objectives of this study, thirty schools were randomly selected from a senatorial district in Oyo State. The Yoruba language teachers of these schools were observed while they taught in the classroom. Three research questions were raised and answered. Data gathered were analyzed using descriptive statistics (frequency, percentage, mean, standard deviation and independent samples t-test). Findings revealed that teachers were generally dominative in their teaching approach in the classroom as most classes were characterized by monologue. Lectures dominated majority of the classes observed. Also, there was no significant statistical difference in the pattern of teacherstudent interaction between private and public school Yoruba language teachers observed. School type did not significantly predict whether a Yoruba language teacher would be dominative or integrative in his or her method of teaching. However, private school Yoruba language teachers had a greater Integrative-Dominative ratio as they encouraged more student-talk in their classrooms. Based on the findings, it was recommended that Yoruba language teachers should try as much as possible to use other teachings methods aside monologue, they should encourage students to ask questions, they should exercise full control over their classrooms and reduce the amount of noise and confusion in their classes. Educational planners and administrators should avail Yoruba language teachers the opportunities of attending seminars, workshops and trainings to keep them abreast with effective methods of teaching. Also, the use of ICT in teaching Yoruba language should be encouraged and teachers who have degrees in the field should be employed and well remunerated.
\end{abstract}

keywords: Assessment, Dominative and Integrative Behaviour, Yoruba Language, Teachers, Senior Secondary Schools

Proceedings Reference Format

Abijo, J.A. (2021): Assessment of Dominative and Integrative Behaviour of Yoruba Language Teachers in Senior Secondary Schools in Oyo State Nigeria. Proceedings of the 28th iSTEAMS Intertertiary Multidisciplinary Conference. American Int University West Africa, The Gambia. October, 2021. Pp 31-46. www.isteams.net/gambia2021.

DOI - https://doi.org/ 10.22624/AIMS/iSTEAMS-2021/V28N2P3 


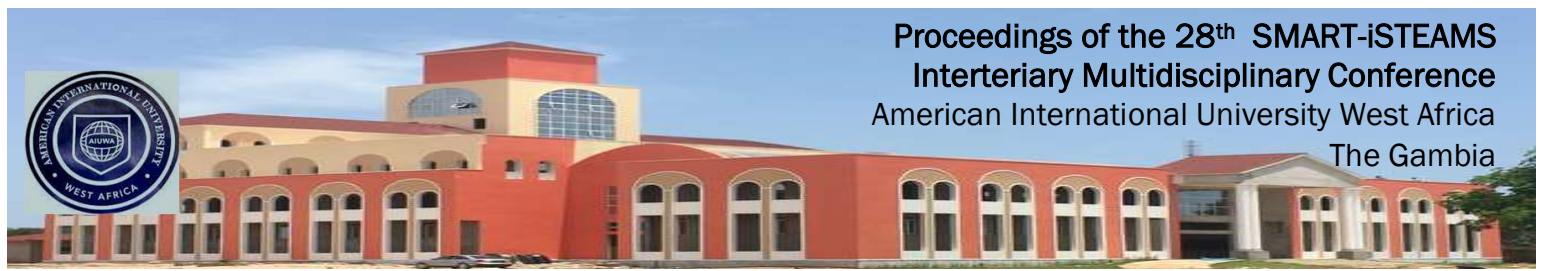

\section{INTRODUCTION}

Yoruba language is taught in Nigeria schools (public and private) right from kindergarten to University level. Also, it is a policy that Yoruba language as one of three main languages in the country should be used as language of instruction for pupils right from lower basic 1 to lower basic three, not only that, the Government considered it to be in the interest of national unity that each child should be encouraged to learn not only his own mother tongue but also another Nigeria language. The skills involved in the teaching and learning of Yoruba language includes reading, writing, speaking and listening

The teaching and learning of Yoruba language in Nigeria will be effective, promoting students interest and achievement, meet global standards and international best practice if the students are taken into full consideration by enabling him or her to play active roles in class activities and the entire learning process. Ideally, learning should be orchestrated by the teacher to make students active and learn meaningfully as well as understand the purpose of learning.

The teaching of Yoruba language should be based on the philosophy of active learningparticipation. According to Piaget (1956), learner-participation is the process whereby students are encouraged to learn by constructing their own knowledge based on what they already understand as they make connections between new information and old information as guided by the teacher. With regards to this philosophy, students are encouraged to discover new concepts based on the activities they perform.

Bello (2007) posited that a learning environment is expected to be democratic, the activities should be interactive and student-centered, and also, the teacher facilitate the process of learning in a way that students are encouraged to be responsible and autonomous. In secondary schools in Nigeria, Yoruba language classes as scheduled on the timetable usually last for 40 minutes and this class is usually scheduled to hold two or three times a week. During the 40 minutes allotted to the lesson, the teacher is expected to interact with students through the instructional process. It is therefore pertinent to observe how the teacher goes about delivering instruction to the students because research conducted by (Adegoke 2003, Akinsola 2000, Isuigo Abanihe 2005) showed that if a classroom climate is friendly, students will develop a positive attitude towards learning and this in turn improves their achievement. Assessment of the form of interactions in Yoruba language classes during teaching-learning process is important as this will provide information on how teachers interact with their students and vice versa.

In recent years, techniques have been developed solely for the purpose of objectively analyzing classroom behaviour and these techniques have paved way into understanding the teachinglearning process and the pattern of classroom interaction. Classroom interaction is simply the interpersonal relationship between students and their teachers. Akinsola (2000) submitted that classroom interaction refers to the activities that take place in the classroom between the teacher and the students which has an anticipated result. 


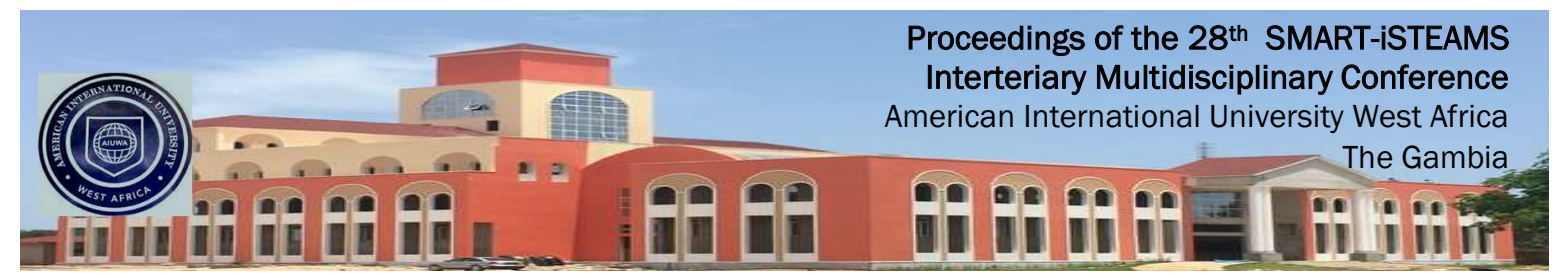

Okoye (2009) stated that classroom interaction is the sum total of activities that take place in the classroom between the teacher, students and the learning materials during the teaching process. Classroom interaction therefore captures both verbal and non-verbal aspects of an instructional process.

Interaction analysis is a process of encoding and quantifying classroom behaviour of teacher and students. In the coding process, categories of classifying statements are established and a code a symbol is assigned to each category. Interaction analysis is used as a technique to capture both qualitative and quantitative dimensions of teacher's and student's verbal behaviour in the classroom. Interaction analysis is an analytical observation scheme that helps to study what a teacher does while teaching in the classroom. It is a systematic observation that represents a useful means of identifying, studying, classifying and measuring specific variables as the teacher and the students interact within the learning environment. The purpose of developing the observational system is to ensure that a teacher can be trained to use it for analyzing classroom behaviour for planning, studying his/her teaching activities in order to create more effective classroom learning.

Research has showed that there are differences in the pattern of how teachers begin their classes and the pattern of interaction that take place during the instructional process. The sequence of the behaviour of teachers varies from teacher to another and this has educational implications on the achievement of students in Yoruba language. Anderson and his group are one of the earliest to work in this direction. They studied the reaction gotten from students based on the type of contracts and influence used by their teachers in the classroom. Anderson et al. $(1939,1945,1946,1946 a)$ explained the types of teachers behaviour in terms of Integrative and Dominative contracts. They found out that pupils whose teachers were Integrative were spontaneous, intelligent and showed acts of problem solving while students whose teachers were Dominative were more easily distracted from school work and showed compliance to teacher's dominance. According to Okilagwe (2011), teacher's style of communication in the classroom has a great effect on meaningful and effective learning, ideally, a good teacher is expected to encourage learner's active involvement in individual and group activities (Akinsola 2000).

Flanders Interaction Analysis Category System (FIACS) has made it possible to get a comprehensive descriptive of the verbal behaviour of both teachers and students in the classroom. Flanders interaction sheet has categories that tests for the direct and indirect teacher and student behaviours of teachers are characterized by teacher behaviour that accepts student feelings and ideas; it reassures students and encourages them. It also involves them in classroom discussions by seeking their response to questions. Such Indirect influences stimulate student talk in response to teacher questions and student talk that is student initiated. The Direct influences tend to increase teacher participation and to establish restraints on student's behaviour in such teacher behaviours as lecturing, giving directions and criticizing or justifying authority. In summary, teacher influence stimulates compliance. 


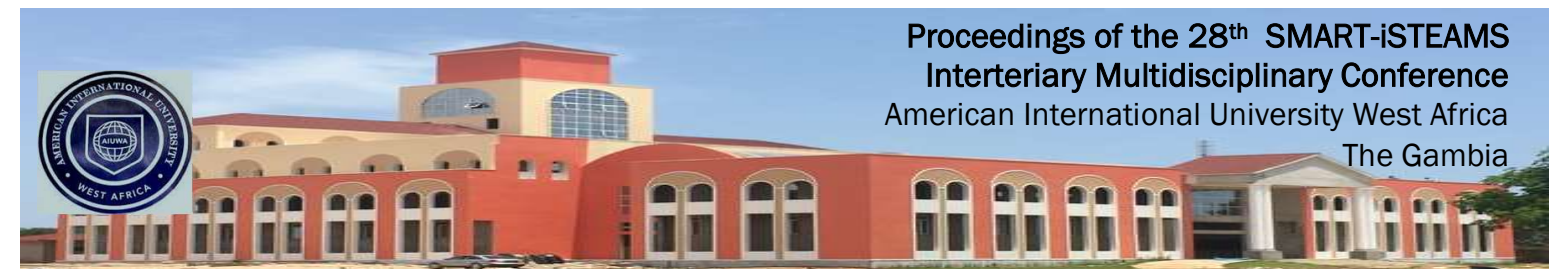

The Flanders system can also be used to calculate the Integrative-Dominative ratio. Teachers with Integrative versus Dominative ratio greater than one are classified as having adopted the Integrative approach in teaching while teacher whose Integrative-Dominative ratio is less than one is classified as having adopted a Dominative approach. Domination is characterized by inflexibility, rigidity, unwillingness to admit the contribution of students amongst others. According to FIACS, the Integrative approach is characterized by teacher accepting feelings, praising or encouraging students, accepting ideas and asking questions while the Dominative approach is characterized by learning, giving directions, criticizing or justifying authority.

Teachers do not have to be Dominative in the classroom however, over the years, experience has shown that students tend to comport themselves better when they have strict teacher who hardly allows students active participation during the lesson. They tend to behave properly during classes, they are more focused and they do every assignment due to the strict nature of their teacher. This invariably affects their achievement positively. The pattern and sequence of teacher-student interaction may result to better student achievement or vice versa, it is therefore important to know through observation the kind of teacher behaviour that really translates into improved achievement and positive attitude towards learning.

Although some researchers have been carried out in the area of teacher-student interaction, this aspect of using FIACS is to observe the pattern of teacher-student interaction in the classroom. For instance, Adegoke (2007) investigated the pattern of teacher-pupils' integration in the classroom and learning outcomes in primary science. He argued that pupils' learning outcomes improves when teachers give maximum opportunities for pupils to participate actively in the teaching and learning activities in the classroom. Though he found out patterns of teacher-pupil interaction in primary science which was classified as either Dominative or Integrative, he did not make use of a language class.

Owodunmi (2015) carried out a study on "Influence of Classroom Interaction patterns on Student Achievement in Basic Electricity at Technical Colleges in Federal Capital Territory, Abuja". He found out that classroom interaction patterns significantly influenced students' achievement in Basic Electricity but his work was limited to influence of classroom interaction on achievement in Basic electricity but not on language. The available literature thus reveal that much is yet to be done, by way of research and observation on language most importantly Yoruba language class to find out the actual pattern of classroom interaction in terms of Teacher talk, Student talk and Silence, how many teachers adopted the Integrative teaching approach and Dominative teaching approach, the Integrative-Dominative ratio and Revised IntegrativeDominative approach ratio of the teacher-student interaction.

Okoye and Onwuachu (2018) investigated the influence of classroom interaction patterns on achievement in Biology among Senior Secondary School Students in Anambra State .Results showed among others that classroom interaction patterns significantly influenced students' achievement in Biology. Similarly, Okafor (2000); and Kalu (2015); found a positive relationship between classroom interaction and students' level of achievement. None of these studies were carried out in the subject area of Yoruba language. 


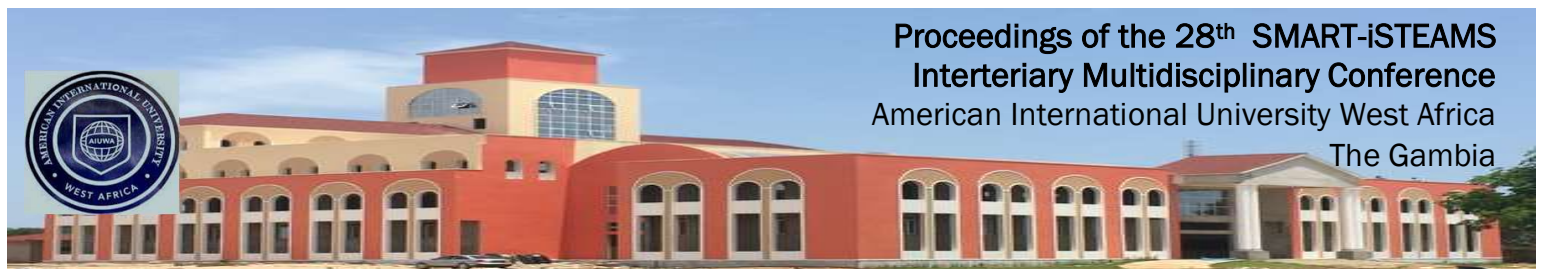

Veronical Odiri Amatari (2015) in her article tiled the Instructional process: a review of Flanders Interaction Analysis in a classroom setting examined critically classroom communication using the interaction analysis. She called for the adoption of this technique in the teaching-learning process in our primary and secondary schools however, she suggested the need to test the use of this in a language classroom in order to determine the congruence between a theoretical and practical context of FIACS as a veritable tool for establishing interpersonal relationship between teachers and students. This study looks to resolve that. Also, several studies have been carried out in other countries. They reported significant and crucial role of teacher-student interaction in the classroom (e.g Pianta, Mashburn, Downer, Hamre and Justice, 2008; Wei, Den Brok, and Zhou, 2009; Wentzel, 1998, 2012). All these studies did not look at the combined effect of the pattern of teacher-student interaction on student learning of Yoruba language.

Public secondary schools are supported and controlled by the government of the state. Adeyinka (2010) stated that public schools are those schools that were established, managed, financed, as well as supervised by the government. He further opined that those schools were established with the tax payer's money in order to educate the generality of the people irrespective of their economic, social or political status in the society. Public secondary schools are neither controlled by individuals, private interest groups or agencies but by the government. After the creation of Nigeria, all the schools that were established were under the management and control of either federal or state government. All subjects were taught at the schools. But after some years most public schools started suffering repercussion of neglecting the teaching of some subjects in public secondary schools.

These subjects include Yoruba language, French, History and Computer Science amongst others. Mojeeb Alabi in National mirror of September 23rd 2012 opined that Yoruba language and History as a subject seemed to be receiving less attention; he attributed the problem to constant changes in government policy. He stated that Nigeria's educational policy is seriously unfriendly to local contents in the curriculum. Lack of adequate funding, poor teacher's salary among others adversely affect classroom interaction which in turn affects teaching and learning in most public schools. As a result of this, private individuals, private groups and organizations started to establish, manage and finance private schools to educate children and also make profit. The owners and proprietors of those private schools are profit earners due to the fact that they invested their money in building the schools, providing all the necessary facilities and equipment, employment of qualified and competent teachers for the purpose of giving good education to children and also making profits.

These private schools include in their curriculum all the subjects especially those not done in public schools. Nwangwu (2000) stated that the private schools offer what public schools cannot provide and they relieve parents the burden of having their children stay at home for long periods of time as a result of continuous strikes by teachers in the public schools. He stated that private schools run without disruption in the schools calendar thereby providing steady and quality education unlike public schools. Okpara (2000) observed that in NECO Examinations, the performances of students in private schools are better than the performance of students in public schools. He also stated that private schools are closely monitored and supervised by the school management boards, as a result; they perform better in external examination. 


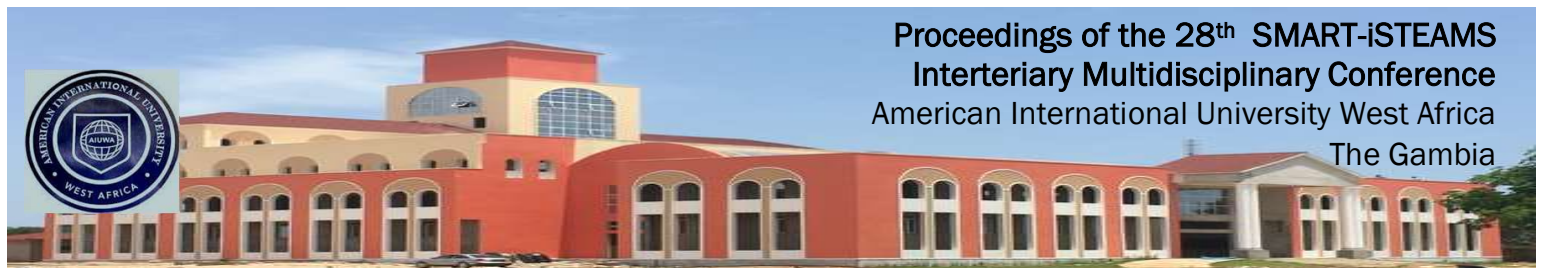

Another factor that can affect student achievement is threshold time. This is the time a teacher takes to prepare when he enters the class before he starts teaching. Akinsola and Okpala (2001) defined threshold time as the minimum time required by a teacher to expose his typical classroom interaction pattern to the students during teaching-learning process. Intensive effort is being made to find a way to reduce threshold time as much as possible so that the available time meant for teaching on the school time table will be effectively and efficiently used for real teaching.

The time used for teaching is actually the time difference between the allotted time for the class and the time taken by the teacher to warm up. Experience has showed that some teachers may use less than five minutes to set the climate in the classroom while others may use up to ten minutes out of the allotted time for the class before the real teaching starts. The time spent by teachers in setting the climate usually has an effect on the overall time needed for the instructional process. Time management during the teaching-learning process is an issue that requires much attention. It appears teachers do not consider this aspect very important during the teaching-learning process is an issue that requires much attention. It appears teachers do not consider this aspect very important during teacher-student classroom interaction. And this may have a significant effect on the educational system.

A teacher who has good knowledge or mastery of the subject matter may not have proper skills in time management and vice versa. Meanwhile, an important aspect of teacher qualities that is supposed to be assessed is how he or she manages time during teaching. The educational significance of measuring this is that it provides empirical information on which aspect of instruction delivery that is predominant or suffers less time or which aspect is being totally neglected during teaching and learning.

According to Bloom's Taxonomy which was created in 1956, there are three domains of learning. If for instance in the Cognitive domain a teacher neglects the evaluation aspect, it is likely that the essence of teaching may not be realized because it is the evaluation aspect that will justify if students have really understood what has been taught or not. Therefore, a teacher's ability to manage time properly is an important issue in classroom interaction. Based on the foregoing, it has been seen that it is important to study classroom interaction in enhancing student achievement. To do this, it is important to carry out an assessment of teacher-student interaction and other dimensions of interactions that takes place in the classroom.

A fundamental contribution to learning process and the effectiveness of teaching is interactions between students and teachers. For students to achieve high in Yoruba language, the teacher has to use a strategy which enable the students to understand language concepts and create conducive environment that will enhance effective teacher-student interaction. Students do not learn optimally by just sitting in classroom and listening to their teachers. Lessons especially language lessons need to be student centered. According to Lara (2012), Instructor-centered teaching focuses on the teacher as both authority and model. The instructor determines the content and organization of the course to a great extent. 


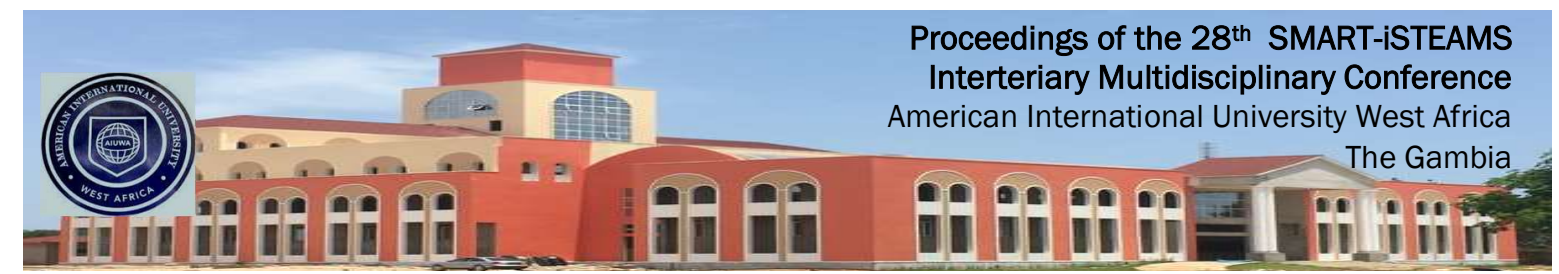

The students are only recipients of the instructor's knowledge. Meanwhile, Student-centered teaching focuses on the student. Decision-making, organization, and content are largely determined by the student's need and perceptions. The instructor only acts as a coach and facilitator. In many respects, the goal of this type of teaching is the development of the student's cognitive abilities.

In this study, analyzing Yoruba language classroom interaction is appropriate by using Flanders Interaction Analysis Categories System (FIACS) although the researcher will be making use of the 13-category modified version of FIACS since the technique is usually used to measure how much the teacher and students spend talking during an instructional process and the pattern with which this occurs. Flanders (1970 as cited in Walsh 2006) divides teacher talk into Accepts feelings, Praises or encourages, Accepts or uses ideas of students, Asks questions, Lectures, Gives direction and Criticizes or uses authority.

He divided Students talk into Response and initiation. He also noted Silence as a period of silence or confusion. To use FIAC, it is necessary to plot a coded data with a constant time before putting the data into an observation tally, FIACS suggests that the constant time to make a tally is every three seconds. It means that the researcher has to use every three seconds to decide which one of the categories of teacher talk, student talk or silence should be marked in the observation sheet.

\subsection{Statement of the Problem}

The interaction between teachers and students in the classroom and also among students has been seen over time to be a crucial aspect of an instructional process. It has also been submitted by researchers that this relationship can produce positive learning outcomes and achievement in students. Past studies on assessment of classroom climate have documented some information about what transpired in the classroom and the relationships between patterns of teacher-student classroom interaction and learning outcomes (achievement and attitude). However, detailed information on this in Yoruba language class is yet to be well documented.

This study unravel the Dominative and Integrative behaviours of teachers in Yoruba language classes using the 13-category modified version of Flanders Interaction Analysis Category System. It also assessing the behavioural pattern and interaction between teachers and students in Yoruba language classes using the modified version of FIACS in both public and private schools.

Specifically, this study investigated how teachers deliver the Yoruba language curriculum and how students react when they are being taught. 


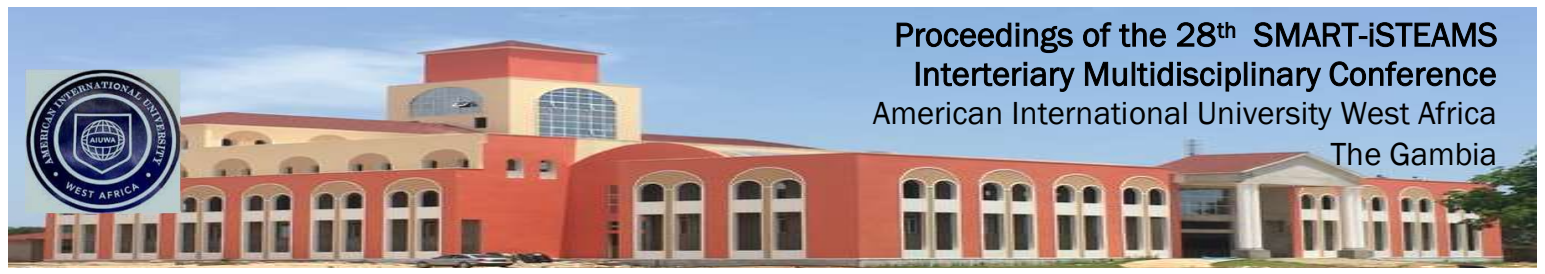

\subsection{Research questions}

The research questions considered for this study include:

1. Using Flanders' 13-category system, what is the pattern of teacher-student interaction in Yoruba language in terms of?

a. Teacher talk?

b. Student talk?

c. Silence?

2. Using Modified Flanders 13-Category interaction system MFCIS, is there any difference in the pattern of teacher-student verbal interaction between teachers in public schools and teachers in private school in terms of:

i. Teacher talk?

ii. Student talk?

iii. Silence?

3. What is the Integrative-Dominative ratio of the teacher-student interaction

i. $\quad$ For all the sampled teachers?

ii. $\quad$ For teachers in private as well as public schools

\section{METHODOLOGY}

Survey design was adopted for the study. Teaching-learning activities in the classroom was observed. This study made use of Multi-stage sampling procedure to select its participants. In Oyo State there are three senatorial districts.

Firstly, one senatorial district was randomly selected from the three senatorial districts. Secondly, simple random technique was used to select six Local Government Areas from the selected senatorial district. Thirdly, five schools were randomly selected from each of the selected Local Government Areas of which three were public schools and two were private schools to make a total of thirty schools which was used for the study.

Finally, from each of the selected school, SS two class was used making a total of thirty classes. Furthermore, this study made use of Yoruba language teacher teaching in each class making a total of thirty SS 2 Yoruba language teachers. In a school that had more than one arm of SS 2, only one arm was selected for the study. An intact class was used for the study. The choice of SS 2 class was because the students would have acclimatized with the conditions of the school environment including the teachers and they are not under any examination pressure. 


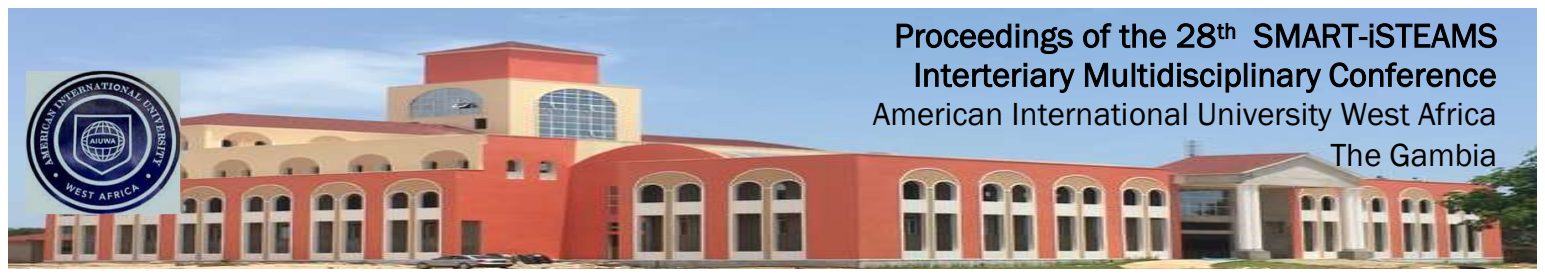

\section{RESULT}

\section{Research Question 1}

Using Flanders' 13-category system, what is the pattern of teacher-student interaction in Yoruba language
i. Teacher talk?
ii. Student talk?
iii. Silence

Descriptive statistics of percentage and frequency counts were used in answering this research question.

Table 1: Pattern of teacher-student interaction

$\begin{array}{llcc}\text { S/N } & \text { Categories } & & \\ \text { A } & \text { TEACHER TALK } & \text { Frequencies } & \text { Percentages (\%) } \\ 1 & \text { Accepts Feelings } & 26 & 1.13 \\ 2 & \text { Praises or Encourages } & 63 & 2.73 \\ 3 & \text { Accepts or Uses Ideas of Students } & 72 & 3.12 \\ 4 & \text { Asks Questions } & 190 & 8.23 \\ 5 & \text { Lectures } & 1214 & 52.58 \\ 6 . & \text { Answers Student Questions } & 70 & 3.03 \\ 7 . & \text { Gives Directions } & 30 & 1.30 \\ 8 . & \text { Criticizes or Justified Authority } & 36 & 1.58 \\ 9 . & \text { Corrective Feedback } & 18 & 0.78 \\ & & & \\ \text { B } & \text { STUDENT TALK } & & \\ 10 & \text { Student-Talk Response } & 189 & 8.19 \\ 11 & \text { Student-Talk Emitted } & 36 & 1.56 \\ 12 . & \text { Student Questions } & 16 & 0.69 \\ \text { C } & \text { SILENCE } & & \\ 13 & \text { Silence } & & \\ & \text { Grand Total } & 349 & 15.11 \\ & & 2309 & \end{array}$

Table 1 above presents the summary of the frequencies and percentages of the categories in the 13-category modified version of FIACS in all the Yoruba language classes observed during the course of this research work. During the course of teaching and learning, teacher talk which comprises of categories $1-9$, constitutes $74.45 \%$ of all the interactions that took place in the classroom. The table also shows that student talk constitutes $10.44 \%$ of all the verbal interactions that took place in the classroom. Silence constitutes $15.11 \%$ of all the interactions that took place in the classroom. A clearer explanation of the table above shows that lectures has the highest percentage of $52.58 \%$ which implies that Yoruba language teachers dominated the process of teaching and learning in the classroom. 


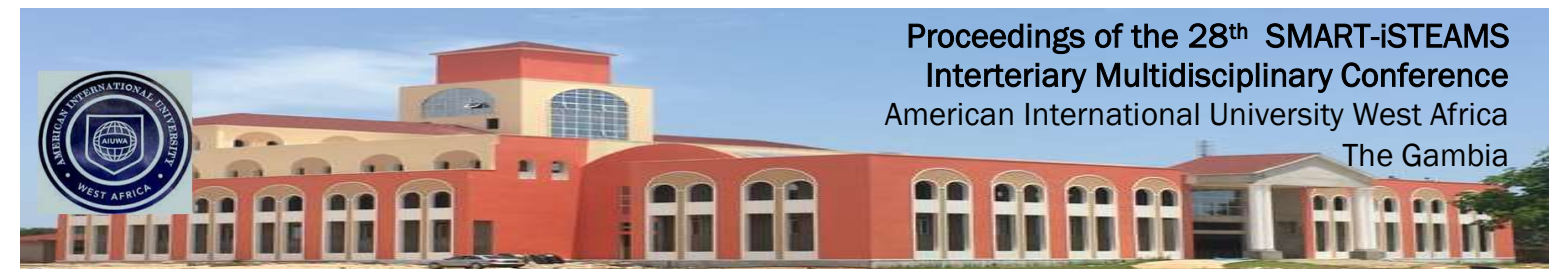

This is also reflected in the percentage of student talk which is $10.44 \%$. with reference to the analysis of the results as shown above, talking by both the teachers and students constitutes $84.89 \%$ of the allotted time for Yoruba language classes wile Silence constitutes $15.11 \%$.

\section{DISCUSSION OF FINDINGS}

The results of the study connotes that the frequency of Lectures which is the fifth category of FIACS is 1214 and that is $52.58 \%$ of all the interactions observed. This means that teachers talked continuously during the classes and they spent greater part of the time allotted for the lesson explaining the topic of the day to the students. This therefore did not give room for students participation while he explained the topic to them.

The result above implies that a larger number of the teachers observed adopted the dominative approach of teaching which is characterized by teacher giving lectures, giving directions, justifying authority. However, according to the result, the category most emphasized on is category 5 which is lectures.

This is in agreement with the findings of Adegoke (2007) and Isuigo-Abanihe and Long John (2005). Isiugo-Abanihe and Long John (2005) who found out in their research work that teacherstudent talk constituted about $83.5 \%$ of the instructional time in a typical science lesson in junior secondary schools in Port Harcourt, Nigeria.

Research question 2: Using Modified Flanders 13-Category interaction system MFCIS, is there any difference in the pattern of teacher-student verbal interaction between teachers in public schools and teachers in private schools in terms of:
i. Teacher talk?
ii. Student talk?
iii. Silence?

To answer this research question, descriptive statistics of frequency counts, percentages, mean, standard deviation and t-test were used. Table 2 outlines the pattern of teacher-student verbal interaction with respect to school type. 


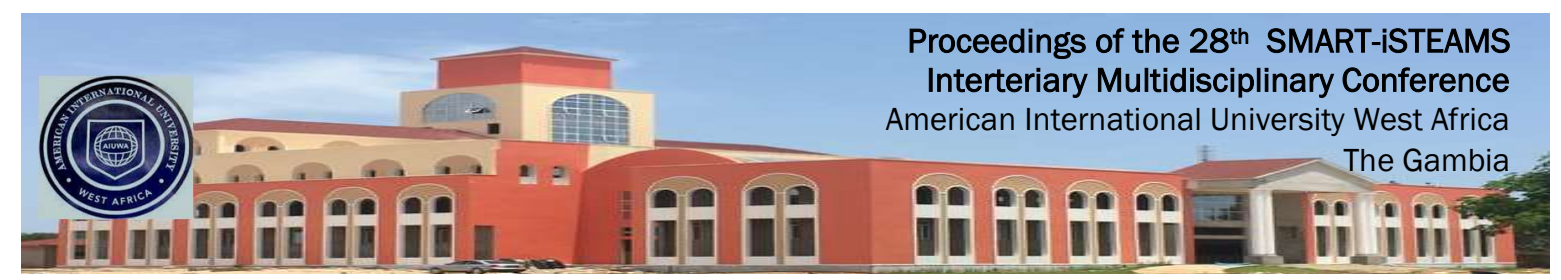

Table .2: Pattern of teacher-student verbal interactions with respect to school type

\begin{tabular}{|c|c|c|c|c|c|c|c|c|c|c|}
\hline \multirow[t]{3}{*}{$\mathrm{S} / \mathrm{N}$} & \multirow[t]{3}{*}{ Category } & \multicolumn{8}{|c|}{ Frequencies, Percentages And Mean } & \multirow{3}{*}{$\mathrm{t}$} \\
\hline & & \multicolumn{4}{|c|}{ Private Schools (12 Schools) } & \multicolumn{4}{|c|}{ Public Schools (18 Schools) } & \\
\hline & & $\mathrm{F}$ & $\%$ & $\bar{y}$ & S.D & $\mathrm{F}$ & $\%$ & $\bar{y}$ & S.D & \\
\hline $\bar{A}$ & TEACHER TALK & & & & & & & & & \\
\hline 1 & Accepts Feeling & 9.00 & 0.95 & 0.75 & 0.87 & 17.00 & 1.24 & 0.94 & 0.94 & -0.573 \\
\hline 2 & $\begin{array}{ll}\text { Praises or } \\
\text { Encourages }\end{array}$ & 25.00 & 2.65 & 2.08 & 2.50 & 38.00 & 2.78 & 2.11 & 1.75 & -0.036 \\
\hline 3 & $\begin{array}{l}\text { Accepts or Uses } \\
\text { Ideas of } \\
\text { Students }\end{array}$ & 15.00 & 1.59 & 1.25 & 1.91 & 57.00 & 4.17 & 3.17 & 2.56 & -2.216 \\
\hline 4 & Asks Questions & 52.00 & 5.51 & 4.33 & 2.17 & 138.00 & 10.10 & 7.67 & 5.68 & -1.888 \\
\hline 5 & Lectures & 531.00 & 56.31 & 44.25 & 9.17 & 783.00 & 50.00 & 37.94 & 12.82 & 1.468 \\
\hline 6 & $\begin{array}{l}\text { Answers } \\
\text { Student } \\
\text { Questions }\end{array}$ & 37.00 & 3.92 & 3.08 & 6.92 & 33.00 & 2.42 & 1.83 & 5.42 & 0.554 \\
\hline 7 & $\begin{array}{l}\text { Gives } \\
\text { Directions }\end{array}$ & 9.00 & 0.95 & 0.75 & 0.764 & 21.00 & 1.54 & 1.17 & 1.30 & -1.004 \\
\hline 8 & $\begin{array}{ll}\text { Criticizes } & \text { or } \\
\text { Justified } & \\
\text { Authority } & \end{array}$ & 15.00 & 1.59 & 1.25 & 2.64 & 21.00 & 1.54 & 1.17 & 1.30 & 0.117 \\
\hline 9. & $\begin{array}{l}\text { Corrective } \\
\text { Feedback }\end{array}$ & 9.00 & 0.95 & 0.75 & 1.14 & 9.00 & 0.66 & 0.50 & 1.04 & 0.620 \\
\hline B & STUDENT TALK & & & & & & & & & \\
\hline 10 & $\begin{array}{l}\text { Student-talk } \\
\text { response }\end{array}$ & 79.00 & 8.38 & 6.58 & 9.30 & 110.00 & 8.05 & 6.11 & 4.40 & 0.189 \\
\hline 11 & $\begin{array}{l}\text { Student-talk } \\
\text { emitted }\end{array}$ & 19.00 & 0.15 & 1.58 & 1.564 & 17.00 & 1.24 & 0.94 & 1.765 & 1.015 \\
\hline 12 & $\begin{array}{l}\text { Student } \\
\text { questions }\end{array}$ & 8.00 & 2.01 & 0.67 & 2.015 & 8.00 & 0.59 & 0.44 & 0.856 & 0.418 \\
\hline $\mathrm{C}$ & SILENCE & & & & & & & & & \\
\hline 13 & Silence & 135 & 14.32 & 11.25 & 7.263 & 214.00 & 15.67 & 11.89 & 7.095 & -0.239 \\
\hline & Grand Total & 943 & $100 \%$ & & & 1366 & $100 \%$ & & & \\
\hline
\end{tabular}

\subsection{Differences in the pattern of teacher-student verbal interaction between Private and Public Schools Yoruba language teachers}

For Private school Yoruba language teachers observed, teacher talk which is from categories19 constitutes $74.44 \%$ of all the verbal interactions in the classroom. The table above shows that student talk has a percentage of $11.24 \%$ while silence constitutes $14.32 \%$ of all the classroom interactions observed in private schools. However, the category that has the highest frequency of interaction in teacher talk is lectures which is category 5 . As show in the table above, in the categorization of Yoruba language teacher talk by means of frequency counts of interactions in public school, teacher talk has a frequency of 702 (dominative) while student talk has a frequency of 106 (integrative). 


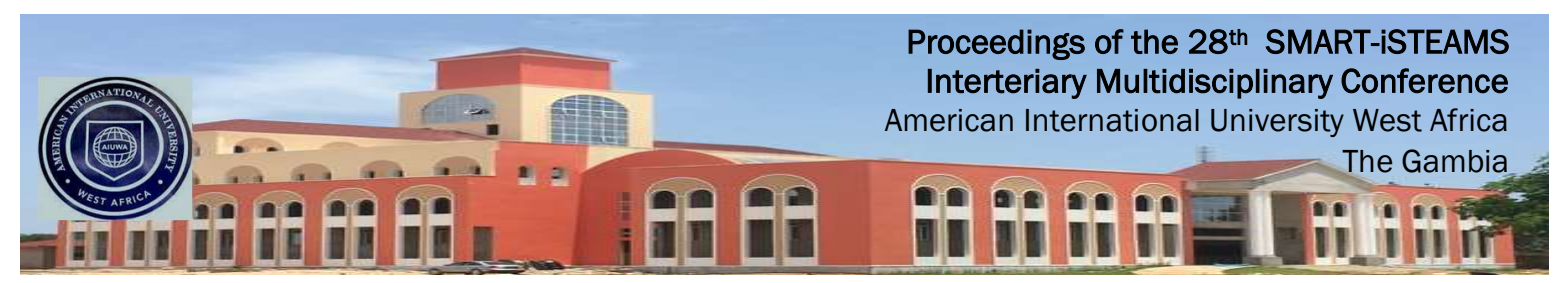

Silence has a frequency of 135 . The total frequency counts for all the interaction observed is 943. An integrative-dominative ratio of approximately 0.15 (1:15) was calculated. This means that for every 15 statements made by the teacher, there was 1 statement from the students.

For Public school Yoruba language teachers observed, teacher talk which is from categories 19 constitutes $74.45 \%$ of all the verbal interactions in the classroom. The table above shows that student talk has a percentage of $9.88 \%$ while silence constitutes $15.67 \%$ of all the classroom interactions observed in private schools. However, the category that has the highest frequency of interaction in teacher talk is lectures which is category 5 . In the categorization of Yoruba language teacher talk by means of frequency counts of interactions in public school, teacher talk has a frequency of 1017 (dominative) while student talk has a frequency of 135 (integrative). Silence has a frequency of 214. The total frequency counts for all the interaction observed is 1366 . An integrative-dominative ratio of approximately 0.13 (1:13) was calculated. This means that for every statements made by the teacher, there was 1 statement from the students.

\subsection{Differences}

Table 3: Pattern of teacher-student verbal interactions with respect to school type based on mean and standard deviation of teacher talk, student talk and silence.

\begin{tabular}{|l|l|l|l|l|l|l|l|}
\hline S/N & Categories & \multicolumn{2}{l}{$\begin{array}{l}\text { Private School (12 } \\
\text { Schools) }\end{array}$} & \multicolumn{2}{l|}{$\begin{array}{l}\text { Public School (18 } \\
\text { Schools) }\end{array}$} & T & P \\
\hline & & Y & S.D & У & S.D & & \\
\hline 1 & Teacher talk & 58.50 & 6.67 & 56.50 & 9.86 & 0.613 & 0.545 \\
\hline 2 & Student talk & 8.83 & 9.79 & 7.50 & 4.61 & 0.503 & 0.619 \\
\hline 3 & Silence & 11.25 & 7.26 & 11.89 & 7.09 & -0.239 & 0.813 \\
\hline
\end{tabular}

As showed in Table.3 above, the average value of frequency counts in the three categories of the 13-category modified version of FIACS is grouped into was calculated. The mean difference for each of these three categories were then analyzed using t-test. This was done in order to ascertain if there was a significant difference in the pattern at which teacher-student interaction occurred in Yoruba language classes in public and private schools. It can be seen that there is no statistically significant difference between Yoruba language teachers in public and private schools. For example, looking at teacher talk, the mean value for private schools is 58.50 (S.D $=6.67$ ) while that of public schools is $56.50(S . D=9.86), t=0.613$ and $p>0.05$.

This connotes that Yoruba language teachers in private and public schools were dominative in their teaching approach. Under the category of student talk, Yoruba language teachers in private school gave more room for students to participate in teaching-learning activities, however, the mean difference is no statistical significant difference between private and public schools since $t=-0.239$ and $p>0.05$. however, silence and confusion was more frequent in Yoruba language classes in public schools. 


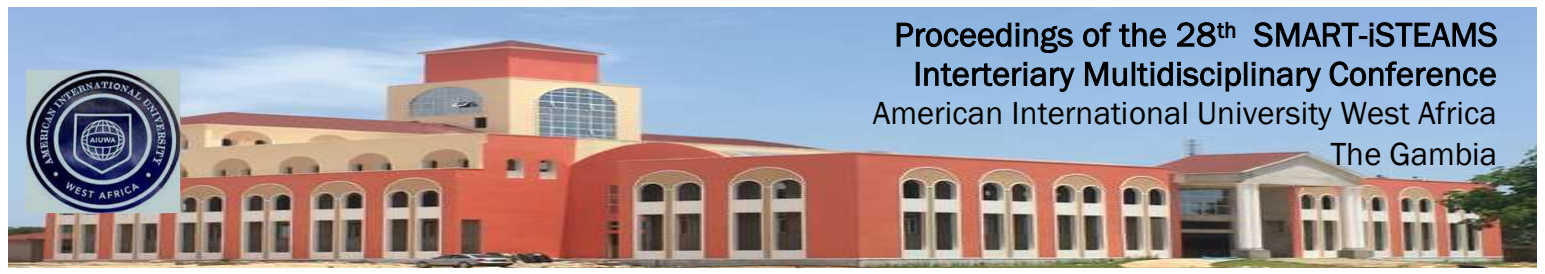

\section{DISCUSSION OF FINDINGS}

According to the results, it was discovered that Yoruba language teachers in both private and public schools were dominative in their method of instruction delivery. Result of analysis done also revealed that there was no significant statistical difference in the categories teacher talk, student talk and silence. This means that there is no statistically significant difference in school type in terms of their classroom interaction patterns. A reason for this may be that teachers no longer passionate about their jobs and profession.

The findings on influence of school type on students' academic performance are controversial. The present study has shown that school type had no significant influence on the pattern of classroom interaction. The finding contradicts the assumption of some parents that students in private schools had better academic performance than those in public schools because of the way teachers teach them in the classroom. The finding of the study supports that of keeves (1978) while it contradicts that of Ajayi (1999). This might be attributed to the fact that both schools were financed, maintained, supervised and controlled by the government. The findings of this study also contradicts that of Ogunleye and Odubunmi and Balogun that school type contributed significantly to the achievement of students in chemistry.

Research question 3i:

What is the Integrative-Dominative ratio of the teacher-student interaction for all the sampled teachers?

Table 4.4: Pattern of Integrative-Dominative ratio of teacher-student interaction of all sampled teachers

\begin{tabular}{|c|c|c|c|}
\hline $\mathrm{S} / \mathrm{N}$ & Categories & Frequencies & Percen \\
\hline A & TEACHER TALK & & \\
\hline 1 & Accept Feelings & 26 & 1.13 \\
\hline 2 & Praises or Encourages & 63 & 2.73 \\
\hline 3 & Accepts or Uses Ideas of Students & 72 & 3.12 \\
\hline 4 & Ask Questions & 190 & 8.23 \\
\hline 5 & Lectures & 1214 & 52.58 \\
\hline 6 & Answers Student Questions & 70 & 3.03 \\
\hline 7 & Gives Directions & 30 & 1.30 \\
\hline 8. & Criticizes or Justifies Authority 36 & 1.58 & \\
\hline 9. & Corrective Feedback & 18 & 0.78 \\
\hline B & STUDENT TALK & & \\
\hline 10 & Student-Talk Response & 8.19 & \\
\hline 11 & Student-Talk Emitted & 36 & 1.56 \\
\hline 12 & Student Questions & 16 & 0.69 \\
\hline C & SILENCE & & \\
\hline 13 & Silence & 349 & 15.11 \\
\hline & Grand Total & 2309 & \\
\hline
\end{tabular}




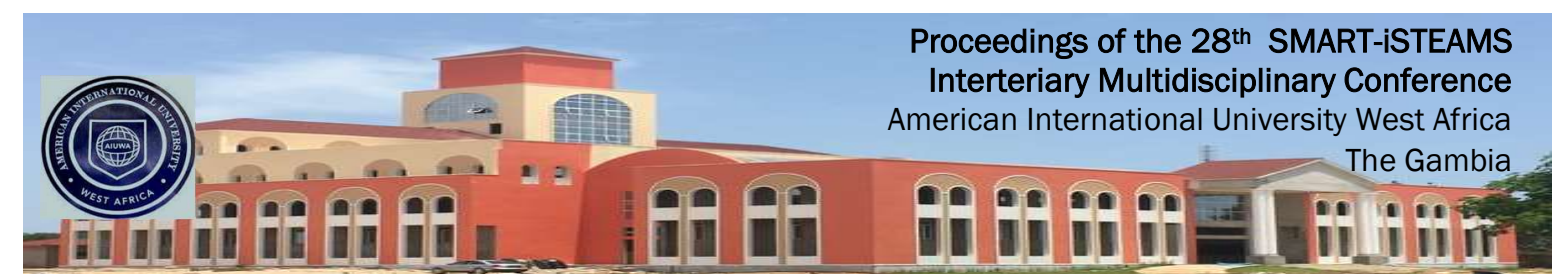

Table 4 above presents the summary of the frequencies and percentages of the categories in the 13-category modified version of FIACS in all Yoruba language classes observed during the course of this research work. During the course of teaching and learning, teacher talk which comprises of categories $1-9$, constitutes $74.45 \%$ of all the interactions that took place in the classroom. The table also shows that students talk constitutes $10.44 \%$ of all the verbal interaction that took place in the classroom. Silence constitutes $15.11 \%$ of all the interactions that took place in the classroom.

According to the table shown, there are a total of 2309 frequency counts of the teachinglearning interaction that took place in all the classrooms observed in this research work. However; $74.45 \%$ of the interaction was teacher-centered (dominative) while $10.44 \%$ was student-centered (integrative). An integrative-dominative ratio of approximately 0.14 (1:14) was calculated. This implies that, for every 14 statements uttered by the Yoruba language teachers, there was only one statement from the students.

Research question 3ii:

What is the Integrative-Dominative ratio of the teacher-student interaction for teachers in private as well as public schools?

To answer this research question, descriptive statistics of frequency counts, percentage and bar chart were used.

Table 5: Integrative - Dominative ratio of teacher-student interaction with respect to school type

\section{$\mathrm{S} / \mathrm{N} \quad$ Categories}

A TEACHER TALK

1 Accept Feelings

2 Praises or Encourages

3 Accepts or Uses Ideas of Students

4 Ask Questions

5 Lectures

6 Answers Student Questions

7 Gives Directions

8. Criticizes or Justifies Authority 15

9. Corrective Feedback

B STUDENT TALK

10 Student-Talk Response 79

11 Student-Talk Emitted

12 Student Questions

C SILENCE

13 Silence

Grand Total

\section{Private Schools Public Schools}

F $\%$ F $\%$

$\begin{array}{llll}9 & 0.95 & 17 & 1.24\end{array}$

$\begin{array}{llll}25 & 2.65 & 38 & 2.78\end{array}$

$\begin{array}{llll}15 & 1.59 & 57 & 4.17\end{array}$

$\begin{array}{llll}52 & 5.51 & 138 & 10.10\end{array}$

$\begin{array}{llll}531 & 56.31 & 683 & 50.00\end{array}$

$\begin{array}{llll}37 & 3.92 & 33 & 2.42\end{array}$

$\begin{array}{llll}9 & 0.95 & 21 & 1.54\end{array}$

$\begin{array}{lllll}1.59 & & 21 & 1.54 & \\ 9 & 0.95 & & 9 & 0.66\end{array}$

$\begin{array}{lll}8.38 & 110 \quad 8.05\end{array}$

$\begin{array}{llll}19 & 2.01 & 17 & 1.24\end{array}$

$\begin{array}{llll}8 & 0.85 & 8 & 0.59\end{array}$

$\begin{array}{llll}135 & 14.32 & 214 & 15.67 \\ 943 & & 1366 & \end{array}$




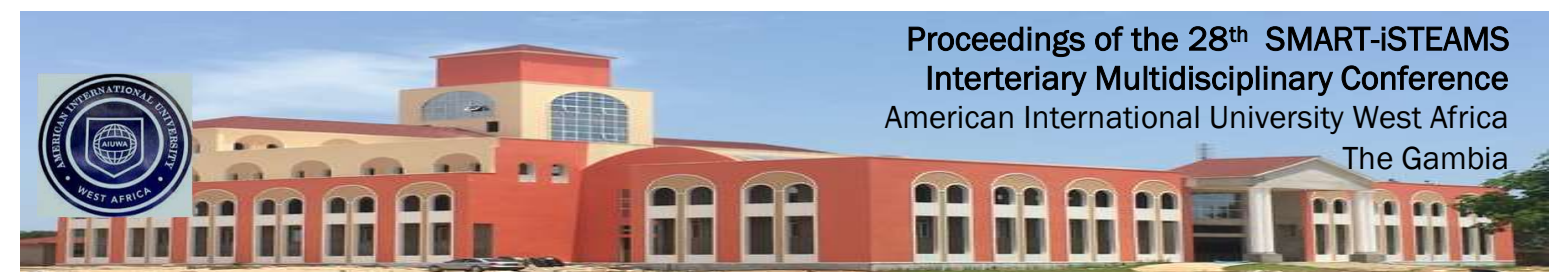

Table 5 above presents the summary of the frequencies and percentages of the categories in the category modified version of FIACS in all the Yoruba language classes observed during the course of this research work.

For private schools, during teaching and learning activities, teacher talk which comprises of categories $1-9$, constitutes $74.44 \%$ of all the interactions that took place in the classroom. The table also shown that student talk constitutes $11.24 \%$ of all the verbal interaction that took place in the classroom. Silence constitutes $14.32 \%$ of all the interactions that took place in the classroom. In the categorization of private schools teacher talk, as shown in the table $4.3 \mathrm{a}$ above, it can be seen that the total frequency counts for all interactions in private school as observed is 943 of which $74.44 \%$ were teacher-centered (dominative) while $11.24 \%$ were student-centered (integrative). An integrative-dominative ratio of approximately 0.15 (1:15) was calculated. This implies that for every 15 statements made by the private school Yoruba language teachers, there was only one statement from the students.

For public schools, during teaching and learning activities, teacher talk which comprises of categories $1-9$, constitutes $74.45 \%$ of all the interactions that took place in the classroom. The table also shows that student talk constitutes $9.88 \%$ of all the verbal interactions that took place in the classroom. Silence constitutes $15.67 \%$ of all the interactions that took place in the classroom. In the categorization of private schools teacher talk, as shown in table 4.3a above, it can be seen that the total frequency counts for all interactions in private school as observed is 1366 of which $74.45 \%$ were teacher-centered (dominative) while $15.67 \%$ were studentcentered (integrative). An integrative-dominative ratio of approximately 0.21 (1:21) was calculated. This implies that for every 21 statements made by the public school Yoruba language teachers, there was only one statements from the students.

\section{Discussion of findings}

Findings has it that majority of the teachers observed during the course of this work are dominative in their approach to teaching. This also goes in line with the results of the analysis which has it that both private and public school Yoruba language teachers have talk as the predominant approach to teaching.

The result above implies that a larger number of the teachers observed adopted the dominative approach of teaching which is characterized by teacher giving lectures, giving directions, justifying authority. This is in line with the findings of Adams and Biddle (1970) in their study of first, sixth and eleventh grade teachers where they discovered that teachers were the most popular actors in $84 \%$ of classroom communication episodes and that less than $1 / 2 \%$ of classroom verbal behaviours were spent in discussion of feelings and interpersonal relations. According to Flanders, teachers spend two-thirds of their teaching-learning time either disciplining or organizing classroom activities thereby leaving students with little opportunity to participate actively in their own learning process. However, this is contrary to the findings of Liu and Elicker (2005) who found that when teachers asked specific questions or asked for students' help, student felt more confident and secure. 


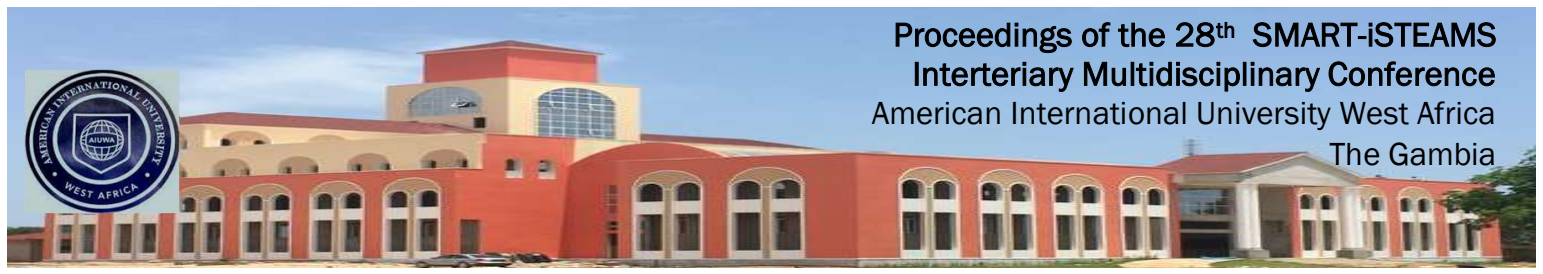

\section{RECOMMENDATIONS}

Based on the findings of this research work, the following recommendations were made:

1. Yoruba language teachers should try as much as possible to use other teaching methods that facilitate learning by allowing students to participate during teachinglearning process.

2. Yoruba language teachers should reduce the amount of time they spend on monologue to allow more of student-talk.

3. Educational planners, administrators and evaluators should supervise, monitor and coordinate the activities of school heads, teachers and students.

4. There is need for more in-service training for teachers to equip them better. Language education program need to integrate pedagogy and content so that the teachers may not only be prepared with respect to a specific subject content but on teaching strategies, varieties of instructional tools and classroom management that can make language period a transforming teaching-learning experience.

\section{REFERENCES}

1. Adegoke, B.A. 2007. Patterns of Teacher-Pupils Interaction in the classroom and Learning Outcomes in

2. primary science. West African Journal of Education (WAJE), vol. xxii. Pp 124-134

3. Okoye, N.S. 2009. The effect of gender Socio economic status and school Location On students' performance in Nigeria Integrated science. Journal of Sciences Education vol.2. 23-34

4. Anderson, H.H 1939. The measurement of Dominative and socially integrative Behavior in Teachers' Contact with children. Child Development. Vol. 10Pp 73-89

5. Anderson, H.H and Brewer, J.E 1946. Studies of Teacher classroom personalities, I. Effect of Teacher Dominative and Integrative contact on children's classroom Behavior Applied Psychology Monography No 6

6. Okurilagire, E.A. 2011. Teaching and Learning Secondary School Geography in Nigeria Stirling Horden Publishers Ltd.

7. Owodunni, A.S 2015. Influence of classroom Interaction patterns on student Achievement in Basic Electricity at Technical Colleges in Federal Capital Territory, Abuja. A paper presented in the international conference on $21^{\text {st }}$ century Educational HCT Dubai men's college, U.A.E, November 2015. Vol.7, No 1 pp 144-153

8. Okoye, N.S. 2018. The effect of gender, socio-Economic status and school location on Students' performance in Nigeria Integrated Science. Journal of science Education vol.2. 23-34

9. Pianla, R, La Paro, K.M and Hamre, B.K 2008. Classroom assessment scoring system manual: k-3.Baltinmore, M.D: Brookers publishing

10. Akinsola, O.S and Okpala, P.N. 2001. A Survey of Threshold Time for classroom interaction Patterns of mathematics Teacher Trainees in Two Nigeria States. A Journal of the International center for Educational Evaluation (ICEE) Institute of Education, University of Ibadan, and The Nigeria Association of Program Evaluators (NAPE) vol. 1, No 1 pp 23-29

11. Lara, V. 2012. Professional development module: student-centered teaching http://www.texascollaborative.org/stdtcenteredteach.htm. Retrieved March 5, 2012

12. Ogunleye, B.O Evaluating the environmental aspect of the senior Secondary School chemistry curriculum in Ibadan unpublished PhD Thesis, University of Ibadan, Ibadan, Nigeria. 